\title{
Cytokines in the Treatment of Cancer
}

\author{
Kevin C. Conlon, Milos D. Miljkovic, and Thomas A. Waldmann
}

Cytokines are major regulators of innate and adaptive immunity that enable cells of the immune system to communicate over short distances. Cytokine therapy to activate the immune system of cancer patients has been an important treatment modality and continues to be a key contributor to current clinical cancer research. Interferon alpha (IFN $\alpha$ ) is approved for adjuvant treatment of completely resected high-risk melanoma patients and several refractory malignancies. High-dose interleukin-2 (HDIL-2) is approved for treatment of metastatic renal cell cancer and melanoma, but both agents are currently less commonly used with the development of newer agents. Granulocyte-macrophage colony-stimulating factor (GM-CSF), IFN gamma (IFN $\gamma$ ), IL-7, IL-12, and IL-21 were evaluated in clinical trials and remain part of certain investigational trials. The initial single-agent clinical trials with the long-awaited IL-15 have been completed and combination trials with antitumor antibodies or checkpoint inhibitors (CPIs) have been initiated. However, cytokines in monotherapy have not fulfilled the promise of efficacy seen in preclinical experiments. They are often associated with severe dose-limiting toxicities that are manageable with appropriate dosing and are now better understood to induce immune-suppressive humoral factors, suppressive cells, and cellular checkpoints, without consistently inducing a tumor-specific response. To circumvent these impediments, cytokines are being investigated clinically with new engineered cytokine mutants (superkines), chimeric antibody-cytokine fusion proteins (immunokines), anticancer vaccines, CPIs, and cancerdirected monoclonal antibodies to increase their antibody-dependent cellular cytotoxicity or sustain cellular responses and anticancer efficacy. In this review, we summarize current knowledge and clinical application of cytokines either as monotherapy or in combination with other biological agents. We emphasize a discussion of future directions for research on these cytokines, to bring them to fruition as major contributors for the treatment of metastatic malignancy.

Keywords: cytokines, interferons, GM-CSF, IL-2, IL-7, IL-12, IL-15, IL-21

\section{Introduction}

@ YTOKINES ARE MOLECULAR messengers of the innate and adaptive immunity that enable cells of the immune system to communicate over short distances in paracrine and autocrine manner. Considering the ability of the immune system to recognize and destroy cancer cells, there has been considerable interest over the past decades in harnessing cytokines for the treatment of cancer. Preclinical experiments with interferon alpha (IFN $\alpha$ ), granulocyte-macrophage colonystimulating factor (GM-CSF), interleukin (IL)-2, IL-12, IL-15, and IL-21 have shown efficacy in multiple murine cancer models (Goldstein and Laszlo 1988; Dranoff 2004; Lee and Margolin 2011; Nicholas and Lesinski 2011; Sim and Radvanyi 2014; Ardolino and others 2015; Floros and Tarhini 2015; Waldmann and Chen 2017). IFN $\alpha$ was the first cytokine approved for the treatment of human cancer, hairy cell leukemia (HCL) in 1986, and after evaluating many treatment regimens, high-dose IL-2 (HDIL-2) was approved for the treatment of metastatic renal cell carcinoma (mRCC) in 1992, and metastatic melanoma (MM) in 1998. Since the initial approval, IFN $\alpha$ has added indications for follicular lymphoma, adjuvant melanoma, mRCC combined with bevacizumab, and AIDS-related Kaposi's sarcoma. Nevertheless, cytokines as monotherapy have not fulfilled the initial excitement they induced.

There are a number of factors that have limited the efficacy of these immunotherapeutics. The addition of cytokines does not direct the immune response to a specific tumor, but requires that the host initiates an immune response, although inadequate to their tumor, which the cytokine can augment. An additional impediment for cytokines like IL-2 is that their positive actions are paralleled by induction of immunological checkpoints such as cytotoxic T-lymphocyte-associated 4 (CTLA-4), programmed death protein-1 (PD-1, CD279), and PD-1 ligands PD-L1 (CD274, B7-H1) and PD-L2 (CD272, B7-DC). Cytokine stimulation also induces the secretion of inhibitory factors such as IL-10 and transforming growth 
factor (TGF- $\beta$ ), the expression of inhibitors such as triosephosphate isomerase (TIM), and the activation of immunedampening cells, including regulatory $\mathrm{T}$ cells (Tregs) and myeloid-derived suppressor cells (MDSC), as well as the activation of intracellular suppressors of cytokine signaling (CIS, SOCS) proteins that terminate the CD4 T cell immune response (Sckisel and others 2015). While cytokines such as IL-2 or IL-15 dramatically increase the number of activated natural killer (NK) cells, these effector cells are inhibited by the interaction of self-class I-A, B, major histocompatibility complex (MHC) molecules with recognition and killer-cell immunoglobulin (Ig)-like receptors (KIRs), and MHC selfclass I-E with NKG2A that are upregulated by immune stimulation. Soluble cytokines normally act over short distances in a paracrine or autocrine manner (Rochman and others 2009). Administering cytokines parenterally at higher doses to achieve effective intratumoral concentrations increases the potential for systemic toxicities, sometimes severe, which include hypotension, acute renal insufficiency, respiratory failure, and neuropsychiatric symptoms.

Strategies to address the issue of local versus systemic effects have included local or cavitary cytokine administration and transduction of stimulating or effector cells with genes encoding the cytokine through plasmid or viral delivery to augment the modest success with cytokine monotherapy. Other new approaches include structure-based cytokine engineering to generate "superkines" with increased binding affinity for select receptors to increase antitumor responses and proportionately decrease stimulation of Tregs. The development of chimeric antibody-cytokine fusion proteins and infusion of anticytokines in association with cytokines improve their tumor localization and pharmacokinetics compared to the native molecule. Additional clinical investigations combine cytokines with anticancer vaccines, checkpoint inhibitor (CPI) antibodies (anti-CTLA4 or anti-PD-1/PD-L1), and the injection of cytokines with cancer-directed monoclonal antibodies to increase the antibody-dependent cellular cytotoxicity (ADCC) of these antibodies, thereby augmenting their antitumor efficacy (Becker and others 1996; Carter 2001; Boyman and others 2006; Schrama and others 2006; Levin and others 2012; Spangler and others 2015).

The goal of this article is to review the nature of cytokines involved in cancer immunotherapy, and to discuss their clinical applications with an overview of the open and recruiting trials of each agent listed on the ClinicalTrials.gov website as of January 31, 2018. The article will also emphasize the combination of biological agents, novel delivery mechanisms, and directions for further investigation.

\section{IFN Background}

IFNs identified by Isaacs and Lindenmann are classified by their ability to bind specific receptors for type I (IFN $\alpha$ and IFN $\beta$ ), type II (IFN $\gamma$ ), and more recently described type III (IFNs) (Isaacs and Lindenmann 1957).

\section{Type I IFNs}

Type I IFNs are a family of cytokines that are synthesized by a variety of cells in response to immune stimulation, viral infection, and certain chemical inducers. Twenty IFNs have been identified in humans (Goldstein and Laszlo 1988).
Most of the subtypes belong to the IFN $\alpha$ group, but also include 2 subtypes of beta (I and II) and 1 T-type, IFN $\gamma$. Type I IFNs signal through a pair of receptors, IFNAR1 and IFNAR2 (Constantinescu and others 1994; Muller and others 1994). These IFN receptors signal through receptor-associated JAK1 and TYK2 to initiate signal transducer and activator of transcription 1 (STAT1) and STAT2 phosphorylation (Darnell and others 1994) (Fig. 1). IFN $\alpha$ upregulates MHC class I surface molecules, promotes caspase-dependent apoptosis in certain types of cancer, has antiangiogenic effects on tumor vasculature, polarizes immune responses toward Th1, enhances cytotoxicity and survival of NK cells, induces the generation and survival of CTLs and memory CD8 T cells, and promotes dendritic cell (DC) maturation.

\section{Clinical application of IFN $\alpha$}

Clinically used recombinant IFN $\alpha$ formulations exist in 3 isoforms (alfa-2a, alfa- $2 b$, and alfa-2c). IFN $\alpha$ and Peginterferon alpha $2 \mathrm{~b}$ are approved as adjuvant treatment for patients with completely resected stage III or IV high-risk melanoma as first-line treatment for patients with $\mathrm{mRCC}$ (alfa-2a, and alfa-2b in combination with bevacizumab), AIDS-related Kaposi's sarcoma (alfa-2b), follicular lymphoma (alfa-2b), HCL (alfa-2a, alfa-2b), chronic myelogenous leukemia (Philadelphia chromosome-positive alfa-2a), condyloma acuminata (alfa-2b), and cervical intraperitoneal neoplasms (alfa-2b) (Gutterman and others 1980; Kirkwood and Ernstoff 1984; Windbichler and others 2000). However, in many cases, novel agents or combinations have replaced IFN or relegated it to second-line therapy and beyond.

\section{Malignant melanoma}

In multiple studies, there was a significant improvement in disease-free survival in 10 of 17 comparisons and overall survival in 4 of 14 comparisons (Amato 1999). In a metaanalysis of 7 randomized trials, IFN $\alpha$ produced a statistically significant better survival than those involving either hydroxyurea or busulfan.

A phase II trial containing IFN $\alpha$ with the anti-CTLA-4 antibody, tremelimumab, in patients with advanced melanoma yielded an overall response rate (ORR) of $24 \%$ with longlasting remissions and evidence of downregulation of hostimmune suppressor mechanisms (Tarhini and others 2012).

\section{Hairy cell leukemia}

IFN $\alpha$ treatment resulted in substantial and sustained improvement in granulocyte counts, platelet counts, and hemoglobin levels in $77 \%$ of treated patients with HCL and some improvement with at least minor responses in $90 \%$ (Ratain and others 1985; Gollob and others 2000). Although IFN $\alpha$ is approved for the treatment of patients with HCL, it has been relegated to second-line treatment because nucleoside analog drugs have replaced it as primary therapy.

\section{AIDS-related Kaposi's sarcoma}

IFN $\alpha$ was evaluated in patients with AIDS-related Kaposi's sarcoma with a dose of 30 million units $/ \mathrm{M}^{2}$ administered subcutaneously (SC) 3 times a week. Forty-four percent of asymptomatic patients responded versus $7 \%$ of symptomatic patients (Abrams and Volberding 1986). 


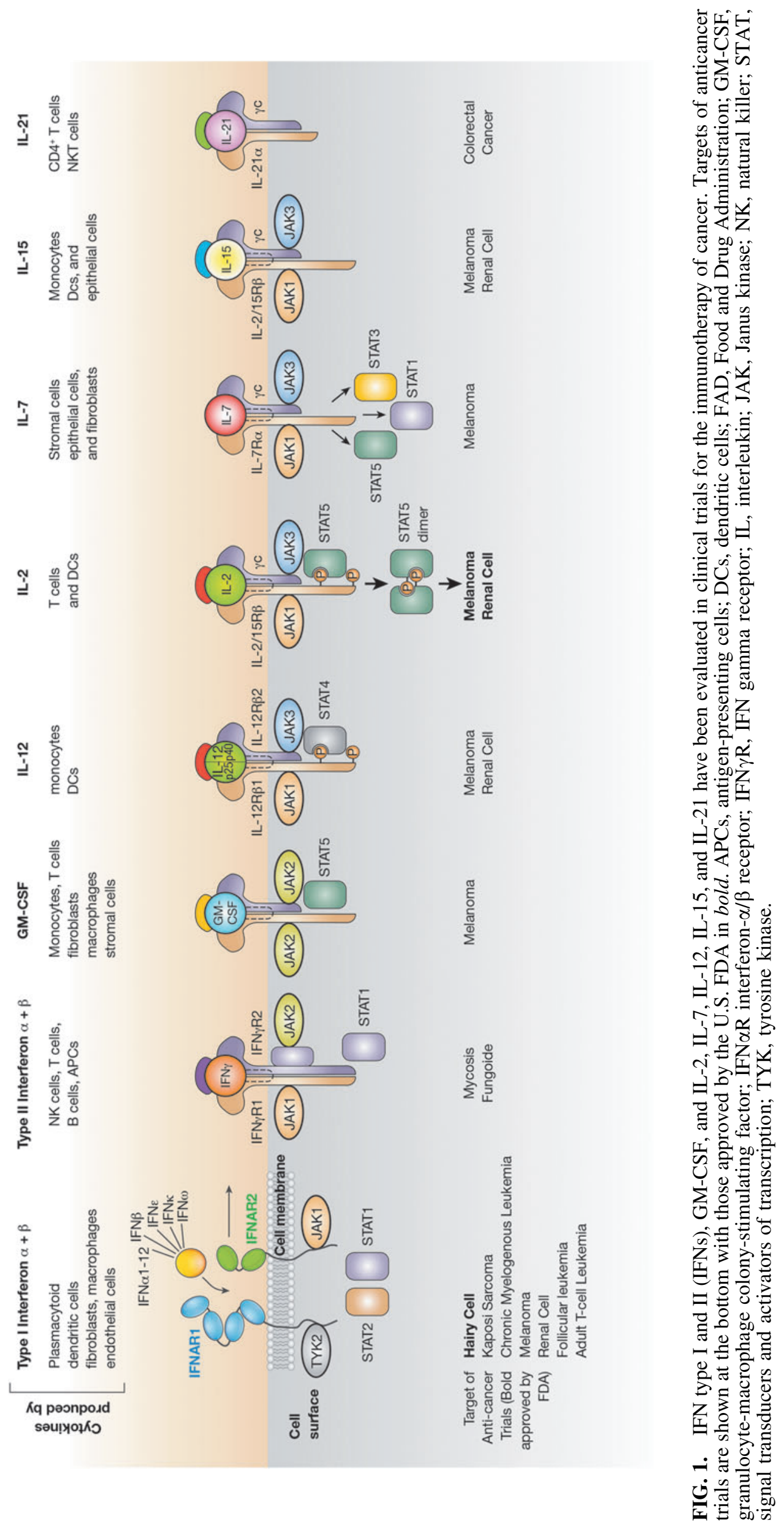




\section{Human T cell lymphotropic-1 associated adult $T$ cell leukemia}

Bazarbachi and others 2010 reported that azidothymidine (AZT) and IFN $\alpha$ plus or minus arsenic therapy were associated with a response in the majority of patients with human T cell lymphotropic-1 (HTLV-1)-associated adult T cell leukemia/lymphoma (ATLL). In a meta-analysis, all patients with the smoldering and chronic forms of this leukemia survived 5 years, whereas $82 \%$ of patients with acute leukemia survived 5 years when treated primarily with this combination. Patients with lymphomatous ATLL or those who had received prior intensive chemotherapy or mutations of p53, or high levels of IRF4 or Rel-c did not respond to AZT and IFN $\alpha$ therapy.

\section{Toxicity}

There can be considerable toxicity generally proportional to the dose and associated with IFN $\alpha$ use (Quesada and others 1986; Jonas and Haluska 2001; Zaidi and Merlino 2011). Constitutional symptoms such as fever, fatigue, headache, gastrointestinal symptoms, and myalgias occurred in $80 \%$ or more of the patients. IFN $\alpha$ also produced increases in hepatic enzymes, particularly during high-dose IV administration. Thrombocytopenia, leukopenia, and neutropenia were common as were neuropsychiatric issues, including depression $(45 \%)$, confusion $(10 \%)$ and mania $(<1 \%)$, electroencephalographic changes, and some cases of suicides.

\section{Current clinical investigations}

IFN $\alpha$ and PEGylated IFN $\alpha$ are still being used as investigational agents in clinical trials in combination with cellular therapies, cancer vaccines, and CPIs, primarily as adjunctive agents (Table 1).

\section{IFN $\gamma S$}

The only cytokine in this family, IFN $\gamma$, is secreted by NK cells, NKT cells, Th1 $\mathrm{CD}^{+} \mathrm{T}$ cells, $\mathrm{CD} 8^{+} \mathrm{T}$ cells, antigenpresenting cells (APCs), and B cells (Frucht and others 2001; Lighvani and others 2001). IFN $\gamma$ binds to the IFN $\gamma$ GR1/IFN $\gamma$ GR2 receptor complex (Fig. 1) on a variety of immune cells, resulting in macrophage activation, induction of MHC class I, MHC class II, and costimulatory molecule expression on APCs, promotion of $\mathrm{CD}^{+} \mathrm{T}$ cell Th1 differentiation, and blockade of IL-4-dependent isotype switching in B cells (Lee and Margolin 2011).

Table 1. Interferon Alpha Trials

\begin{tabular}{lcc}
\hline Formulation & $\begin{array}{c}\text { Number } \\
\text { of trials }\end{array}$ & Therapeutic role \\
\hline $\begin{array}{c}\text { Recombinant } \\
\text { human protein }\end{array}$ & 32 & $\begin{array}{c}\text { Adjunctive immune } \\
\text { activator with } \\
\text { cellular therapies, } \\
\text { CPIs, and vaccines }\end{array}$ \\
\hline
\end{tabular}

CPIs, checkpoint inhibitors.

\section{Clinical applications}

IFN $\gamma$ was initially considered a promising immunotherapeutic based on results in preclinical animal models and was extensively tested in clinical trials. A phase II trial of IFN $\gamma$ given to 15 patients with mycosis fungoides intravenously at a dose of 2 million units daily for 5 days per week over 4 weeks, followed by daily SC administration, showed an objective response rate of $60 \%$, with only 1 patient progressing during the median follow-up of 170 days (Sugaya and others 2014). Despite the initial enthusiasm, IFN $\gamma$ never demonstrated efficacy in oncology patients and its Food and Drug Administration (FDA) approvals are only for chronic granulomatous disease and osteopetrosis-2 nononcologic indications. Proposed reasons for this lack of efficacy have been activation of MDSC and a narrow therapeutic index (Street and others 2002; Lee and Margolin 2011).

\section{Current clinical investigations}

The desirable biologic effects of IFN $\gamma$ still led to some interest as an immunotherapeutic that is being investigated clinically, primarily as an adjunctive stimulator of cellular therapies or CPIs (Table 2).

\section{GM-CSF Background}

GM-CSF is a $23 \mathrm{kDa}$ glycoprotein with a 4 -alpha helical bundle structure that binds to a 2-subunit receptor, a ligandspecific alpha chain, and a common beta chain shared with IL-3 and IL-5 (Fig. 1). GM-CSF is produced by monocytes, $\mathrm{T}$ cells, fibroblasts, endothelial cells, macrophages, and stromal cells (Kurzrock 2000), stimulating the survival of a hematopoietic colony forming cells of neutrophil, eosinophil, macrophage, megakaryocyte, and erythrocyte linages. It also stimulates antigen presentation to the immune system by direct effects on DCs and macrophages with induction of the expression of class II MHC and Fc receptors on these cells. GM-CSF stimulated the capacity of neutrophils, monocytes, and macrophages to mediate ADCC. Recombinant GM-CSF was approved by the FDA to shorten the time to neutrophil recovery and reduce the incidence of infections following induction of chemotherapy in patients with acute myelogenous leukemia. An appreciable increase in side effects largely related to macrophage stimulation limited clinical use of this cytokine for neutrophil recovery in favor of the less problematic G-CSF. In a critical murine study, transfection of B16 melanoma cells with recombinant retroviral vectors expressing nearly all known stimulatory cytokines, costimulatory molecules, or adhesion molecules, GM-CSF, showed greatest efficacy (Dranoff and others 1993). The GM-CSF secreting tumor vaccines conveyed $90 \%$ protection.

Table 2. Interferon Gamma Trials

\begin{tabular}{lcc}
\hline Formulation & $\begin{array}{c}\text { Number } \\
\text { of trials }\end{array}$ & Therapeutic role \\
\hline $\begin{array}{c}\text { Recombinant } \\
\text { human protein }\end{array}$ & 7 & $\begin{array}{c}\text { Adjunctive immune } \\
\text { activator with cellular } \\
\text { therapies or CPIs }\end{array}$ \\
$\begin{array}{c}\text { Cell line or lysate } \\
\text { ther }\end{array}$ & 1 & \\
\hline
\end{tabular}




\section{Clinical applications}

Treatment of autologous GM-CSF-transfected melanoma was evaluated in several trials and produced a consistent infiltration of the tumor deposits by activated DCs, CD8 ${ }^{+}$ lymphocytes, B cells, and interestingly, eosinophils and plasma cells causing appreciable tumor destruction, but also produced exuberant scarring that contributed to a low clinical response rate (Mach and Dranoff 2000; Jinushi 2008; Kaufman and others 2014). Attempts to employ a less cumbersome adenovirus transduction method for producing transfected viable tumor cells suitable for administration were not sufficiently successful and this strategy was eventually abandoned. GM-CSF was evaluated as adjuvant treatment for completely resected stage III/IV melanoma, but data from several clinical trials did not demonstrate consistent efficacy (Spitler and others 2009). Two randomized trials suggested that the addition of GM-CSF to melanoma vaccines did not improve cellular immune responses and indeed may have had negative effects. The inconsistent effects may be caused by contrasting effects of GM-CSF, including DC maturation on the one hand and induction of myeloid suppressor cells on the other (Kaufman and others 2014).

\section{Current clinical investigations}

Because of GM-CSF's well-characterized ability to stimulate antigen presentation by APC forms of the recombinant protein still licensed for neutrophil recovery, the in vivo productions from engineered cell lines, or the transduced tumors or viral delivery systems are all still part of clinical trials (Table 3).

\section{IL-12 Background}

IL-12 is a 4-bundle $\alpha$-helix heterodimeric cytokine that is the first member of the IL-12 cytokine family, which also includes IL-23, IL-27, and IL-35 (Trinchieri 2003). IL-12 consists of p35 and p40 subunits, the latter shared by IL-23 and is mainly secreted from APCs in response to pathogens. The IL-12 receptor (IL-12R) consists of 2 chains IL-12R $\beta 1$ and IL-12R $\beta 2$, and signals predominantly through STAT4 (Trinchieri 2003) (Fig. 1). IL-12 is involved in the differentiation of naive T-helper (Th) 0 cells into Th1 cells, and stimulates the production of IFN $\gamma$ by plasmacytoid DCs and $\mathrm{T}$ cells. IL-12 augments the activity of cytotoxic $\mathrm{T}$ cells and enhances B cell survival. IL-12 induces the production of the chemokine inducible protein-10 (IP-10 or CXCL10), which mediates its antiangiogenic effect (Lee and Margolin 2011).

Table 3. Granulocyte-Macrophage Colony-Stimulating Factor Trials

\begin{tabular}{lcc}
\hline Formulation & $\begin{array}{c}\text { Number } \\
\text { of trials }\end{array}$ & \multicolumn{1}{c}{ Therapeutic role } \\
\hline $\begin{array}{l}\text { Recombinant } \\
\text { human protein }\end{array}$ & 35 & $\begin{array}{c}\text { Stimulation or expansion } \\
\text { of APCs and augmented } \\
\text { antigen presentation }\end{array}$ \\
$\begin{array}{l}\text { Cell line or lysate } \\
\text { Plasmid or virus }\end{array}$ & 13 & \\
\hline
\end{tabular}

APCs, antigen-presenting cells.
IL-12 showed efficacy in a series of preclinical studies in experimental models in mice. Limitations in its use are its induction of negative immunoregulatory IL-10 and TIM3 (Coughlin and others 1998; Gollob and others 2000). A series of clinical trials was initiated with IL-12 in patients with renal cell carcinoma and melanoma with promising preliminary results, but a phase II trial that changed the previously verified dosing schedule resulted in severe grade 3 or 4 fatigue, dyspnea, acidosis, leukopenia, and elevated liver function tests within the first 5 days of treatment. Twelve of 17 enrolled patients required hospitalization with intensive supportive care and there were 2 deaths leading to a temporary halt by the U.S. FDA (Leonard and others 1997; Lasek and others 2014). An explanation for the different tolerability in phase I versus the phase II trial was a change in the dosing schedule. In the phase I trial, a single dose of IL-12 was administered before the multidose regimen. This priming dose was found to be critical for protection from the severe toxicity (Leonard and others 1997). For the most part, the IL-12 clinical program never recovered from this event, even though there was modest efficacy in subsequent trials in cutaneous $\mathrm{T}$ cell lymphoma, Hodgkin's and nonHodgkin's lymphoma, and Kaposi's sarcoma (Gollob and others 2000). The response rate for refractory melanoma patients treated with IL-12 transduced tumor-infiltrating $\mathrm{T}$ cells (TILs) was considerable $(63 \%)$, but duration of response was short and significant treatment-related toxicities were seen leading to the abandonment of this strategy.

\section{Current clinical investigations}

Preclinical results continue to demonstrate IL-12's potential as an immunotherapeutic that is still being assessed in clinical trials (Table 4). NHS-IL-12 is a novel immunokine consisting of $2 \mathrm{IL}-12$ molecules fused to a human IgG1 with affinity for single- and double-stranded DNA exposed in areas of tumor necrosis. NHS-IL-12 has a longer half-life, and improved efficacy and toxicity profile in preclinical models (Fallon and others 2014). This agent is being investigated in several ongoing clinical trials. Other clinical formulations include a new recombinant human protein cell line producing IL-12, or cell lysate or transduced effector cells, or virally transduced tumor cells intended to stimulate effector T cells locally.

\section{IL-2 Background}

IL-2 is a $15.5 \mathrm{kDa}$ glycoprotein of 133 amino acids, which consists of 4 antiparallel amphipathic alpha helices (Waldmann 1986; Taniguchi and Minami 1993; Liao and others 2011; Boyman and Sprent 2012). IL-2 is predominantly produced by

TABLE 4. INTERLEUKIN-12 TRIALS

\begin{tabular}{lcc}
\hline Formulation & $\begin{array}{c}\text { Number } \\
\text { of trials }\end{array}$ & Therapeutic role \\
\hline Protein & 2 & $\begin{array}{c}\text { Stimulation of effector } \\
\text { lymphocytes at the site } \\
\text { of tumor deposits }\end{array}$ \\
$\begin{array}{l}\text { Chimeric immunokine } \\
\text { Cell line or lysate }\end{array}$ & 3 & \\
Plasmid or virus & 6 & \\
\hline
\end{tabular}


antigen-activated Th1 CD4 T cells and to a lesser extent by CD8 T cells, NK cells, and NK T cells. The IL-2 receptor comprises 3 subunits, including the cytokine-specific IL-2R $\alpha$ (CD25), IL-2R $\beta$ (CD-122) shared with IL-15 and IL-2R $\gamma$ (CD132), also known as the common cytokine receptor gamma chain $(\gamma \mathrm{c})$, shared with IL-4, IL-7, IL-9, IL-15, and IL-21. The signal transduction mediated by IL-2 involves the recruitment of Janus family tyrosine kinases (JAK1 and JAK3) to the cytoplasmic domains of IL-2R $\beta \gamma$. Upon the initial activation of JAK1/JAK3, 3 major downstream signaling pathways are activated: the STAT signaling pathway, the phosphoinositide 3-kinase (PI3K-AKT) signaling pathway, and the mitogenactivated protein kinase signaling pathway (Fig. 1). Cellular activation of the JAK kinase results in the recruitment and phosphorylation of STAT5A, STAT5B, and to a lesser extent, STAT1 and STAT3 (Wang and others 2005).

IL-2 not only acts as a $\mathrm{T}$ cell growth factor during the initiation of the immune response but also has a crucial role in terminating $\mathrm{T}$ cell responses to maintain self-tolerance by activation-induced cell death (AICD) of overactive T cells (Lenardo 1996). IL-2 promotes antigen-activated CD8 $\mathrm{T}$ cells and is a growth factor for CD4 T cells as well as NK cells (Boyman and Sprent 2012). Another facet of IL-2's role as a potent negative immune regulator is as a stimulator of immunosuppressive $\mathrm{CD}^{+}{ }^{+} \mathrm{Foxp}^{+}$T-regulatory cells (Tregs) (Sakaguchi and others 1995).

IL-2 ${ }^{-/}$- and IL-2R alpha $^{-/-}$-deficient mice develop massive enlargement of peripheral lymphoid organs associated with polyclonal $\mathrm{T}$ cell and $\mathrm{B}$ cell expansions due to impairment of AICD and deficiencies of Tregs. IL-2R alphadeficient mice develop autoimmune hemolytic anemia and inflammatory bowel disease (Sadlack and others 1994).

\section{Clinical applications}

The FDA approval of HDIL-2 for the treatment of mRCC and $\mathrm{MM}$ was based on data derived from multiple pivotal trials administering IL-2 of 600,000-720,000 IU/ $\mathrm{kg}$ with up to 15 bolus infusions every $8 \mathrm{~h}$ based on patients' tolerance. In 255 patients with mRCC (Rosenberg and others 1989; Fyfe and others 1995; Atkins and others 1999), the ORR was $15 \%$ with $7 \%$ complete responders (CRs). In $270 \mathrm{MM}$ patients, the ORR was $16 \%$ with $6 \%$ CRs with a median response duration of 8.9 months (range 4-106 + months).

Since the recombinant cytokine first became available for clinical use, treatment with IL-2 has been evaluated in many different dose ranges, schedules, and routes of administration in attempts to maximize efficacy and minimize toxicity. While only the HDIL-2 IV bolus regimen is an FDA-approved schedule, positive results have been seen in clinical trials that administered this agent by continuous intravenous (CIV) infusion at lower doses for up to 90 days. This was associated with a significant expansion of $\mathrm{CD}^{+} 6^{+} \mathrm{CD}^{-} \mathrm{NK}$ cells (Caligiuri and others 1993; Soiffer and others 1996; Fehniger and others 2000).

IL-2 is almost universally used with adoptive $\mathrm{T}$ cell therapy (ACT) with TILs harvested from autologous tumor deposits, expanded ex vivo, and reinfused with the HDIL-2 regimen. Multiple clinical trials have demonstrated an $\sim 50 \%$ ORR with $13 \%$ CRs in MM that are durable, often continuing past 5 years. TIL therapy usually given with IL-2 has been investigated in clinical trials for other solid tumor types with mixed success (Andersen and others 2015).
HDIL-2 treatment has also been given in ACT trial evaluating effector $\mathrm{T}$ cells transduced with tumor-specific $\mathrm{T}$ cell receptor ( $\mathrm{Lu}$ and others 2017), and in lower doses for selected trials with chimeric antigen receptor $\mathrm{T}$ cells (CAR-T cells) (Junghans and others 2016).

Despite the proven efficacy of HDIL-2 in treating mRCC and MM patients, wider use remains relatively restricted due to known drawbacks. The binding of IL-2 to high-affinity IL$2 \mathrm{R} \alpha$ - expressing endothelial cells induces acute vasodilation and the vascular leak syndrome (VLS). Other studies suggest that elevated levels of angiopoietin- 2 and eNOS or a protein fragment of IL-2 molecule designated as permeabilityenhancing peptide may contribute to VLS. In addition, as noted above, high-dose IL-2 therapy preferentially induced the expansion of $\mathrm{CD}^{+} \mathrm{CD}^{+} 5^{+}$Foxp $^{+} \mathrm{CD} 127^{-} / \mathrm{lo} \mathrm{PD}^{+}{ }^{+} \mathrm{CD} 39 \mathrm{hi}$ $\mathrm{ICOS}^{+}$Tregs that displayed an immunosuppressive phenotype. Due to the short serum half-life and the need to achieve an immune-modulatory effect in the tissues, IL-2 must be given in high doses that produce severe systemic toxicities, including VLS, pulmonary edema, hypotension, acute renal insufficiency, and rarely myocarditis.

Coincidental to the HDIL-2 trials, attempts to define a lowdose schedule that provided sufficient immune activation with a better tolerated safety profile were examined. These strategies have been based in many cases on the known biology of CD56 $6^{\text {bright }} \mathrm{NK}$ cells that express the high-affinity IL2 receptor. Low-dose IL-2 therapy provided through CIV infusion over the course of 90 days was associated with a significant expansion of $\mathrm{CD}^{2} 6^{+} \mathrm{CD}^{-} \mathrm{NK}$ cells (Caligiuri and others 1993; Soiffer and others 1996; Fehniger and others 2000). Although such prolonged low-dose IL-2 therapy was successful in expanding the number of NK cells, these NK cells were not activated, but required high amounts of IL-2 in vivo to kill tumor cells. Therefore, low-dose IL-2 to expand NK cells was combined with intermediate pulses of IL-2 to provide activation of an expanded NK cell pool (Caligiuri and others 1993). In the last 2 decades of clinical research, many other low-dose IV or SC injection treatments usually given in combination with other immunotherapeutics have been assessed in attempts to define a less toxic activating regimen, but no consensus choice has been identified (Gratama and others 1993; Rotte and others 2015; Gill and others 2016).

\section{Current clinical investigations}

IL-2 continues to be an important part and commonly employed component in cancer immunotherapeutic trials (Table 5). Availability of the licensed recombinant cytokine results in this formulation being the most widely used in current trials, followed by several different chimeric immunokine constructs.

TABle 5. Interleukin-2 Trials

\begin{tabular}{lcc}
\hline Formulation & $\begin{array}{c}\text { Number } \\
\text { of trials }\end{array}$ & Therapeutic role \\
\hline Protein & 66 & $\begin{array}{c}\text { Stimulate and expand T } \\
\text { cells or NK cells }\end{array}$ \\
Chimeric immunokine & 7 & \\
Cell line or lysate & 1 & \\
Plasmid or virus & 1 & \\
\hline
\end{tabular}

NK, natural killer. 


\section{IL-21 Background}

IL-21 is composed of 4-alpha-helical bundles (Spolski and Leonard 2008). It is a member of the common gamma family and shares this chain with IL-2, IL-4, IL-7, IL-9, and IL-15, as well as its cytokine-specific IL-21R $\alpha$ chain. IL-21 has a major role in $\mathrm{B}$ cell differentiation into plasma cells, in the development of $\mathrm{T}$ follicular helper ( $\mathrm{Tfh}$ ) cells, promotes the development of Th17 cells, and enhances the survival, antiviral activity, and antitumor activity of $\mathrm{CD}^{+} \mathrm{T}$ cells (Ma and others 2003; Wang and others 2003; Skak and others 2008; Spolski and Leonard 2014).

Antitumor activity of IL-21 has been shown in several preclinical studies (Skak and others 2008) that showed inhibition of growth of B16 melanoma and MCA205 fibrosarcoma tumors, and increased survival of tumor-bearing mice.

\section{Clinical applications}

Clinical activity, including CRs, was seen in the initial phase I and II clinical trials with IL-21 for patients with $\mathrm{mRCC}$ and MM. As predicted by the preclinical models, appreciable expansion of $\mathrm{NK}$ and $\mathrm{CD} 8^{+} \mathrm{T}$ cells was observed with a side effect profile like that of intermediate-dose IL-2. Additional studies in mRCC continued to show clinical activity for the most part (ORR 8\%-42\%), but severe, sometimes fatal hepatic inflammation at the effective doses was recognized as a limiting factor (Curti 2006). IL-21 was combined with cetuximab (Erbitux), an antibody targeting epidermal growth factor receptor, to augment its ADCC against tumors. In phase I trials, the combination of IL-21 with cetuximab against stage IV colorectal cancer stable disease was achieved in $60 \%$ of patients (Steele and others 2012). However, the clinical trial was terminated when IL-21 was shown to have a role in the development of chronic inflammatory bowel disease, and in promoting the inflammation-induced development of colon cancer (Steele and others 2012). Ultimately issues with severe hepatic or GI toxicities and the lack of consistent clinical activity eventually led to discontinuation of IL-21's clinical development by Pharma.

\section{Current clinical trials}

Administration of the cytokine directly into patients has ceased, but there are still a few trials using the recombinant cytokine to expand effector cells ex vivo (Table 6).

\section{Interleukin-7}

IL-7 is another common $\gamma$ chain (CD132) cytokine, produced by nonhematopoietic stromal and epithelial cells: bone marrow stromal cells, MHC II+ thymic epithelial cells, liver and intestinal epithelial cells, keratinocytes, follicular DCs, smooth muscle cells, and sometimes by DCs and macrophages. Like the IL-21 receptor (IL-21R), the IL-7R

TABLE 6. INTERLEUKIN-21 TRIALS

\begin{tabular}{llc}
\hline Formulation & $\begin{array}{l}\text { Number } \\
\text { of trials }\end{array}$ & Therapeutic role \\
\hline Protein & 3 & $\begin{array}{c}\text { Stimulation of effector } \\
\text { lymphocytes }\end{array}$ \\
\hline
\end{tabular}

only has the common $\gamma$ chain and the IL-7-specific alpha chain (IL-7R $\alpha$ or CD127), which first transmits the activation signal through JAK1 and JAK3 pathways, followed by the STAT5 and the common RAS/RAF/P13K pathway (Fig. 1).

\section{Clinical applications}

Two phase I dose escalation trials were conducted at the National Cancer Institute (Rosenberg and others 2006; Sportès and others 2010). The first-in-human was a dose-escalation trial that administered SC rhIL-7 in conjunction with 2 wellcharacterized melanoma peptides, gp100 and MART-1, mostly to patients with malignant melanoma. The treatment was well tolerated, but no objective responses were seen. In the more recent trial, patients with incurable nonhematologic malignancies were treated with escalating doses of SC rhIL-7 (3 to $60 \mathrm{mcg} / \mathrm{kg}$ ) given every other day for 2 weeks (Capitini and others 2009) without evidence of clinical activity.

Continued clinical development of IL-7 was hampered by the discovery that the original Escherichia coli produced material was extremely immunogenic, causing the development of neutralizing IL-7 antibodies preventing repeated treatment cycles. Subsequent production of a Chinese hamster ovary (CHO)-derived mammalian cytokine did not overcome the lack of interest in exploring oncology indications and largely terminated IL-7 clinical trials.

\section{Current clinical trials}

Like IL-21 administration of the cytokine, IL-7, directly into patients has largely ceased, there are still a few trials using the recombinant cytokine to expand effector cells ex vivo and some discussion of new clinical trials with remaining stocks of clinical grade material or newer constructs in development (Table 7).

\section{IL-15 Background}

IL-15 is a 14 -to- $15 \mathrm{kDa}$ member of the 4-alpha-helix bundle family of cytokines. IL-15 is controlled at the level of transcription, but especially at the level of translation, so that although IL-15 message is widely distributed, it is produced predominantly by DCs, epithelial cells, and monocytes (Bamford and others 1998; Waldmann 2006, 2015). The IL-15 receptor includes the IL-15-specific subunit IL$15 \mathrm{R} \alpha$ and the IL-2/IL-15R $\beta$ subunit shared with IL-2 and the common gamma subunit $\gamma \mathrm{c}$ shared with IL-2, IL-4, IL-7, IL-9, and IL-21. This receptor signals through JAK1, JAK3, and STAT5 and to a lesser extent, STAT3. IL-15 and IL-2 both share functions and have distinct contributions to the immune response (Fehniger and others 2002; Waldmann 2006, 2015; Steel and others 2012). The shared functions include stimulation of the proliferation of activated $\mathrm{T}$ cells, the production of CTLs, and Ig synthesis by B cells that

TABle 7. INTERLEUKIN-7 Trials

\begin{tabular}{llc}
\hline Formulation & $\begin{array}{l}\text { Number } \\
\text { of trials }\end{array}$ & Therapeutic role \\
\hline Protein & 3 & $\begin{array}{c}\text { Stimulation of effector } \\
\text { lymphocytes }\end{array}$ \\
\hline
\end{tabular}


have been stimulated with IgM-specific antibodies or agonistic anti-CD40. The 2 cytokines also stimulate the generation and proliferation of NK cells. In addition to these similarities, there are distinct differences in the adaptive immune response to IL-2 and IL-15. IL-2 acts as a T cell growth factor, but it also has a critical role in terminating immune responses to self by AICD and by the action of Tregs. In contrast, IL-15 has no major net effects on the maintenance of fitness of Foxp3-expressing Tregs. In further contrast to IL-2, IL-15 is an antiapoptotic factor in several systems - in particular in IL-15 transgenic mice, IL-2induced AICD was inhibited by IL-15. Furthermore, IL-15 promotes the maintenance of $\mathrm{CD}^{+} \mathrm{CD} 44^{\text {hi }} \mathrm{T}$-memory phenotype cells.

These observations from ex vivo functional analyses were supported by an examination of mice with disrupted cytokine and cytokine-receptor genes. As noted above, IL-2, IL$2 \mathrm{R} \alpha$, and IL-2-/IL-2R $\beta$-deficient mice developed a marked enlargement of lymphoid organs associated with dysregulated proliferation that reflects the impairment of Treg fitness and AICD (Sadlack and others 1994). In contrast, mice that were deficient in IL-15 or its private receptor, IL-15R $\alpha$, did not develop lymphoid enlargement, increased serum immunoglobulin concentrations, or autoimmune disease. Such mice had a marked reduction in the number of thymic and peripheral $\mathrm{NK}$ cells, NK T cells, $\gamma / \delta \mathrm{T}$ cells, and intestinal intraepithelial lymphocytes (Kennedy and others 2000). A most critical factor in the functional differences between IL-2 and IL-15 involves the fact that IL-2 is a secreted molecule, which in its soluble form binds to preformed high-affinity heterotrimeric receptors at the surface of activated cells. Although IL-15 can signal in cis, IL-15 predominantly signals in the context of cell-cell contact at an immunological synapse in trans (Dubois and others 2002). The IL-15 and IL-15R $\alpha$ expressed by monocytes and DCs become associated on the cell surface and IL-15 is presented by IL-15R $\alpha$ in trans to cells that express IL-2/IL$15 \mathrm{R} \beta$ and $\gamma \mathrm{c}$, but not IL-15R $\alpha$. Such targets of IL-15/IL$15 \mathrm{R}$ alpha trans-presentation include NK cells and CD8 memory T cells (Dubois and others 2002). The distinctions between IL-15 and IL-2, including the fact that IL-15 does not yield stimulated Tregs, AICD, or extensive capillary leak syndrome, suggest that IL-15 may be superior to IL-2 in the treatment of malignancy.

\section{IL-15 in the treatment of cancer}

IL-15 as an immunotherapeutic agent: IL-15 in preclinical immunotherapy models. IL-15 proved to be of value in the therapy of neoplasia in a number of murine models (Evans and others 1997; Fehniger and others 2002; Klebanoff and others 2004; Waldmann 2006; Dubois and others 2008; Zhang and others 2009, 2012; Steel and others 2012; Yu and others 2012). The antitumor effect in many cases was found to be largely dependent on the enhancement of NK cell cytotoxicity and NKG2D-mediated activation of NK cells.

The safety of IL-15 was evaluated in rhesus macaques (Mueller and others 2005; Berger and others 2009; Lugli and others 2010; Waldmann and others 2011). Recombinant human (rh) IL-15 produced in E. coli was administered at a dosing schedule of 12 daily IV bolus infusions at doses of 10,20 , and $50 \mathrm{mcg} / \mathrm{kg} / \mathrm{d}$ to rhesus macaques, with the only biologically meaningfully laboratory abnormality being a grade 3/4 transient neutropenia. A 12-day bolus of IV administration of $20 \mathrm{mcg} / \mathrm{kg} /$ day of IL-15 to rhesus macaques was associated with a 4- to 8-fold increase in the number of circulating NK, stem, central, and effector memory $\mathrm{T}$ cells (Lugli and others 2010; Waldmann and others 2011). IL-15 administered by CIV infusion at $20 \mathrm{mcg} / \mathrm{kg} / \mathrm{day}$ for 10 days led to an $\sim 10$-fold increase in the number of circulating NK cells, and an 80 to 100-fold increase in the number of circulating effector memory CD8 T cells (Sneller and others 2011). Subcutaneous (s.c.) infusions at $20 \mathrm{mcg} / \mathrm{kg} / \mathrm{day}$ for 10 days led to a more modest 10 -fold increase in the number of circulating effector memory CD8 T cells.

\section{Clinical applications}

In the phase I trial of recombinant IL-15 for adults with refractory metastatic malignant melanoma and metastatic cancer, IL-15 was administered as a daily bolus infusion for 12 days. The initial patients at $3 \mathrm{mcg} / \mathrm{kg} / \mathrm{day}$ and $1 \mathrm{mcg} / \mathrm{kg} /$ day developed grade 3 hypotension or grade 3 thrombocytopenia, or persistent grade 3 aminotransferase and aspartate aminotransferase elevations that were dose limiting (Conlon and others 2015). All 9 patients with IL-15 administered at $0.3 \mathrm{mcg} / \mathrm{kg} /$ day received all 12 doses without dose limiting toxicities. The fevers and rigors observed in patients with $3 \mathrm{mcg} / \mathrm{kg} / \mathrm{day}$ were concurrent with a maximum of 50-fold elevations of circulating IL-6 and IFN- $\gamma$ concentrations. Flow cytometry of peripheral blood lymphocytes revealed a dramatic efflux of NK and effector memory T cells from the circulating blood within minutes of IL-15 administration, followed by influx and hyperproliferation that led to a 10fold expansion of $\mathrm{NK}$ and $\gamma / \delta \mathrm{T}$ cells that ultimately returned to baseline. Furthermore, there were significant increases in the number of CD8 memory phenotype T cells. In this first-in-human phase I trial of bolus IL-15, there were no responses, with stable disease as the best response. However, 5 patients manifested a decrease between $10 \%$ and $30 \%$ of their marker lesions and 2 patients had clearing of lung lesions. Among 22 patients receiving IL-15 SC, there was 1 serious adverse event at $2.0 \mathrm{mcg} / \mathrm{kg} /$ day s.c. transient grade 2 pancreatitis. The mean fold increase in circulating NK cells was 10.8fold and the circulating CD8 cell increase was 3.3-fold for the $3.0 \mathrm{mcg} / \mathrm{kg} /$ day dose cohort. In patients receiving rhIL-15 by continuous IV infusion for 10 days, the MTD was $2.0 \mathrm{mcg} / \mathrm{kg} /$ day. Following termination of the infusion, there was a major burst in the number of NK cells that occurred 1 to 2 days following cessation of the infusion, with a 30 -fold increase in the circulating total of NK numbers and a more than 350 -fold increase in the number of CD56 $6^{\text {bright }} \mathrm{NK}$ cells (K Conlon and TA Waldmann, unpubl.).

Fehniger and others (2017) and Romee and others (2016) demonstrated that NK cells after preactivation with IL-12, IL15 , and IL-18, in contrast to IL-15 alone, exhibited enhanced responses to cytokine activating receptor stimulation for weeks to months after preactivation. They demonstrated that memory-ligand NK cells have enhanced IFN $\gamma$ production and cytotoxicity against leukemia cell lines or primary human acute myeloid leukemia (AML) blasts in vitro regardless of KIR to KIR-ligand interactions. In the context of a first-inhuman phase I clinical trial, adoptively transferred memoryligand NK cells proliferated and expanded in AML patients and demonstrated robust responses against leukemia targets. 
Clinical responses were observed in 5 of 9 evaluable patients, including 4 complete remissions.

\section{IL-15/IL-15R alpha}

Although IL-15 may show efficacy in the treatment of patients with metastatic malignancy, it is not optimal when used in monotherapy. There is only a low-level expression of IL-15R $\alpha$ on resting DCs (Chen and others 2012; Vincent and others 2013). IL-15 and IL-15R $\alpha$ are always associated during their production expression and in the circulation (Sandau and others 2004; Mortier and others 2006). Thus, IL-15/IL-15R alpha may be considered a heterodimeric cytokine. Physiologically, IL-15 is produced as a heterodimer in association with IL-15R alpha. Furthermore, in mice, it is the heterodimer alone that is stably produced and transported to the surface of the cell. To address the issue of deficient IL-15R, alpha mammalian IL-15/IL-15R alpha and IL-15R alpha $\mathrm{IgFc}$ have been produced and entered into a large number of clinical trials evaluating patients with metastatic malignancy (Tinhofer and others 2000; Chertova and others 2013). Two clinical trials are IL-15 superagonist ALT-803 "A Phase I Study of the Clinical and Immunological Effects of ALT-803 in Patients with Advanced Sold Tumors," NCT01946789 and "A Phase I Study of Subcutaneous Recombinant Human hetIL-15/IL-15R alpha in Adults with Metastatic Cancers," NCT02452268.

IL-15/IL-15R alpha and IL-15/IL-15R alpha IgFc were shown to have a longer in vivo survival than monomeric IL15 and were 10 -fold more active in augmenting the number of circulating NK cells at the same dose of IL-15. However, both IL-15/IL-15R alpha and IL-15/IL-15R alpha IgFc (ALT-803) when administered SC were associated with up to $30 \mathrm{~cm}$ inflammation-inflammatory lesions of the skin. This adverse event limited the dose of IL-15 that could be achieved, and thereby limited the increase in the number of circulating NK cells to 8-fold when compared to the 30-fold increase achieved with $E$. coli IL-15, an agent that was not associated with skin lesions.

It is clear from the results of clinical trials that IL-15 to make a major impact in cancer therapy must be administered in combination with agents that already have an action, although inadequate in the treatment of cancer.

\section{Current clinical trials}

Agents to relieve checkpoints on the immune system to optimize IL-15 action. IL-15 is associated with the expression of immunological checkpoints, including the expression of PD-1 on CD8 T cells and the production of IL-10 and T cell immunoreceptor with Ig and LTim domains (TIGIT) (Table 8; $\mathrm{Yu}$ and others 2010). To address this issue in murine models, IL-15 was administered with agents to remove such check-

TABle 8. INTERLEUKIN-15 TRIALS

\begin{tabular}{lcc}
\hline Formulation & $\begin{array}{c}\text { Number } \\
\text { of trials }\end{array}$ & Therapeutic role \\
\hline Protein & 12 & $\begin{array}{c}\text { Stimulation of effector } \\
\text { lymphocytes at the site } \\
\text { of tumor deposits }\end{array}$ \\
Plasmid or virus & 1 & \\
\hline
\end{tabular}

points, in particular with antibodies toward CTLA-4 and to programmed death ligand-1 (PD-L1). In the CT26 colon carcinoma and TRAMP-C2 prostatic cancer syngeneic tumor models, IL-15 alone produced only modest antitumor activity. The addition of either anti-CTLA-4 or anti-PD-L1 in association with IL-15 did not increase the action of IL- 15 . However, tumor-bearing mice receiving IL-15 in combination with both anti-checkpoint antibodies manifested a marked prolongation of survival (Yu and others 2010, 2012).

\section{IL-15 in combination with anticancer monoclonal antibodies to increase their antibody-dependent cellular cytotoxicity}

Approaches involving cytokines when used alone depend on the hypothesis that the host is making an immune response, although inadequate, to their tumor and that this action can be augmented by the administration of the cytokine. However, the cytokines could also be used in drug combinations where an additional agent provides specificity directed toward the tumor. IL-15 could be used with anticancer vaccines, cellular therapy, or tumor-directed monoclonal antibodies (Sondel and Hank 1997; Moga and others 2008; Roberti and others 2011). Given the capacity of IL-15 to increase the number and activation state of NK cells and monocytes, a very attractive antitumor combination strategy is to use IL-15 in conjunction with antitumor monoclonal antibodies to augment the ADCC of the latter. Vincent and others (2014) reported highly potent anti-CD20-RIL-I immunocytokine targeting of established B cell lymphomas in severe combined immunodeficiency (SCID) mice. In our studies, 2 murine tumor models, 1 syngeneic model involving EL4 leukemic cells transfected with human CD20 using rituximab, and a second xenograft model involving alemtuzumab, CAMPATH-1/anti-CD52 in a model of adult $\mathrm{T}$ cell leukemia, the addition of IL-15 with the monoclonal antibody dramatically augmented the ADCC of the antibody and its antitumor efficacy. On the basis of these clinical and preclinical observations, a phase I study of subcutaneous IL-15 with alemtuzumab in patients with refractory and relapsed chronic and acute ATL (NCT02-689453) has been initiated. Furthermore, a trial is being initiated in patients with refractory and relapsed chronic lymphocytic leukemia, where IL-15 will be administered in an effort to augment the ADCC and antileukemia efficacy of a CD20-directed monoclonal antibody.

IL-15 plus agonistic anti-CD40 antibody. It has been shown that the administration of $\gamma c$ cytokines leads to the induction of intracellular checkpoints, including cytokine-inducible $\mathrm{SH} 2$-containing protein (CIS) and SOCS3. This expression of SOCS3 leads to inadequate CD4 help and the induction of "helpless" CD8 T cells (Sckisel and others 2015). It was shown that an agonistic anti-CD40 or CD40 ligand can substitute for inadequate CD4 helper cells, thereby leading to the generation of antigen-specific CD8 cytotoxic T cells (Bennett and others 1998; Ridge and others 1998; Schoenberger and others 1998; Sckisel and others 2015). In the murine syngeneic TRAMP-C2 tumor model, we showed that either IL-15 alone or an agonistic anti-CD40 antibody (FGK4.5) prolonged the survival of the TRAMP-C2 tumorbearing mice (Zhang and others 2009, 2012). Moreover, we showed that the combination of IL-15 with anti-CD40 produced markedly additive effects that were curative in the majority of mice when compared to either agent alone. The 
combination circumvented the problem of "helpless" CD8 $\mathrm{T}$ cells, whereas the administration of IL-15 or anti-CD40 alone did not augment the number of tumor-specific tetramer-positive CD8 T cells; the number of TRAMP-C2 tumor-specific SPAS-1/SNC9-H8 tetramer-positive CD8 T cells was markedly augmented by the combination of IL-15 plus anti-CD40 antibody (Zhang and others 2012). It is hoped that with the different approaches discussed, IL-15 will take its place in the combination treatment of cancer.

\section{Approaches to improve cytokine-based immunotherapy}

In view of the limitations of cytokine monotherapy, recent efforts have focused on developing novel cytokines and cytokine mutants, including "superkines." Structure-based cytokine engineering has opened new opportunities for cytokines as drugs with focus on immunotherapeutic cytokines IL-2, IL-4, IL-15, and IFN (Wang and others 2005). The alterations of IL-2 were directed toward reducing its interaction with IL-2R $\alpha$, thereby diminishing its stimulation of Tregs and its interaction with IL-2R $\alpha$ in the vasculature to reduce the capillary leak syndrome and pulmonary edema (Heaton and others 1993; Levin and others 2012; Spangler and others 2015). Heaton and others in early studies generated 2 IL-2 mutants, F42K and R38A, which have altered IL-2R $\alpha$ binding domains; they greatly decrease their binding affinity to IL-2R $\alpha$, while having an affinity similar to that of native IL- 2 to IL-2R $\beta$ and $\gamma \mathrm{c}$. These IL- 2 mutants activated LAK cells without production of high levels of proinflammatory cytokines (IFN- $\gamma$, IL-1 $\beta$, and TNF- $\alpha$ ), and thereby reduced the toxicities caused by the surge of proinflammatory cytokines observed with conventional high-dose IL-2 therapy. Moreover, these IL-2 mutants circumvented binding to IL-2R $\alpha$ expressing endothelial cells and prevented the VLS (Hu and others 2003). These mutants also were less efficient in stimulating the expansion of Tregs.

The Garcia Laboratory also eliminated the functional requirement of IL-2 for IL-2R $\alpha$ expression by engineering an IL-2 "superkine" with increased binding affinity for IL2R $\beta$ (Levin and others 2012). The evolved mutations were predominantly in the core of the cytokine that stabilized IL2 , reducing the flexibility of a helix in the IL- $2 \mathrm{R}$ binding site into an optimized receptor binding confirmation resembling that when bound to CD25. The mutations in IL-2 superkine were comparable to the functional role of $\mathrm{CD} 25$, by eliciting STAT5 phosphorylation. When compared to IL-2, the superkine induced augmented expression of cytotoxic $\mathrm{T}$ cells leading to improved antitumor responses in murine models with less expansion of Tregs and reduced pulmonary edema.

IL-15 has been engineered to exert both increased agonistic and inhibitory effects (Mortier and others 2006; Mitra and others 2015). A truncated version of the extracellular domain of IL-15R $\alpha$ was fused to IL-15 that activated IL$15 R \alpha$-deficient cells by stabilizing the signaling complex formation analogous to the effects of IL-2 superkine on cells that lack IL-2R $\alpha$. The IL-15 fusion protein enhanced the proliferation and antiapoptotic effects of IL-15. Zhu and others (2009) generated agonists of IL-15 by increasing the cytokine affinity for IL-2R $\beta$, thereby stabilizing its interface. Another focus of IL-15 engineering has been to produce antagonists to counteract its immunostimulatory activity. Pettit and others (1997) identified the Q108 residue of IL-15 as critical for $\gamma_{\mathrm{c}}$ interaction, so that when this residue was deleted, it abrogated cytokine-mediated proliferation. Thus, engineered examples of IL-2 and IL-15 could have therapeutic utility in many aspects of immune regulation.

Attempts have been made to enhance IFN antiviral activity using DNA shuffling. DNA sequences from all IFN- $\alpha$ subtypes were combined to generate a shuffled library that was screened for function based on antiproliferative and antiviral activity (Stemmer 1994; Brideau-Andersen and others 2007; Spangler and others 2015). This screening identified 2 shuffled proteins, B9X25 and B9X14, with a 20to 70 -fold improvement in antiviral potencies compared to IFN- $\alpha 2$. The shuffled proteins had 9- to 100-fold increases in the IFNAR complex affinity, respectively, compared to wild-type IFN- $\alpha 2$. Unfortunately, this shuffled IFN did not advance into the clinic because of immunogenicity resulting from numerous mutations found in the shuffled IFN products, which generated new potential $\mathrm{T}$ cell epitopes.

\section{Activating anticytokine immune complexes}

An alternative approach to augment IL-2 action was to employ anti-IL-2 immune complexes (Boyman and others 2006; Young and others 2014). Certain monoclonal antibodies directed toward IL-2 inhibited its action in vitro and in vivo. However other antibodies coupled with IL-2 caused a massive greater than 100-fold expansion of CD8 T cells in vivo, whereas others selectively stimulated $\mathrm{CD} 4^{+}$Tregs. These actions were, in part, due to increases in the in vivo survival of IL-2. This approach allowed the selective modulating effects of IL-2 in the development of cytokinedirected antibodies that directed activity toward specific $\mathrm{T}$ cell subsets. The anti-IL-2 antibody S4B6 blocked the IL-2:IL-2R $\alpha$ interaction confirmation and stabilized the IL$2: I L-2 R \beta$ interaction, thus stimulating IL-2-responsive IL$2 \mathrm{R} \beta^{\text {hi }}$ effector cells favored over IL-2R $\alpha$ expressing Treg cells. Thus, different cytokine-antibody complexes selectively boost or inhibit the immune response.

\section{Cytokine-antibody fusion molecules}

A cytokine-antibody fusion protein is a genetically engineered fusion protein consisting of a functional cytokine with an antibody, with an antigen binding site designed to deliver cytokines to a tumor (Becker and others 1996; Reisfeld and Gillies 1996; Penichet and Morrison 2001). Antibody IL-2 fusion proteins encoding the anti-GD2 gangliocyte binding site have been used against human neuroblastoma tumor in a SCID mouse model. In this system, IL-2 delivery through the fusion molecule enhanced effector $\mathrm{T}$ cell responses and increased tumor cell lysis compared to systemic IL-2 delivery. Phase I and II clinical trials of this recombinant fusion molecule in both melanoma and pediatric neuroblastoma patients have demonstrated its safety at doses that are able to induce immune activation. Furthermore, L19-IL-2 (Darleukin) and hu14.18-IL-2 are currently in phase II clinical studies. L19-IL-2 is a diabody with 2 human IL-2 molecules that are genetically fused to the Cterminus of each scFv domain, whereas hu14.18-IL-2 consists of an IgG antibody to gangliocyte (GD2). A phase I clinical study with hu14.18-IL-2 showed therapeutic potential (Carnemolla and others 2002). Another immunocytokine is focused on engineering IL-15 or IL-15/IL-15R $\alpha$, including 
RIL1 immunocytokine engineered so that the sushi domain of human IL-15R $\alpha$ is linked to human IL-15 and fused to the anti-GD2 to target cancers such as melanoma, glioma, neuroblastoma, and small-cell lung carcinoma. Preliminary studies with immunocytokine indicate a longer half-life of this agent and its potential to mediate ADCC and compliment dependent cytotoxicity. In yet other studies, Young and others (2014) used antibody-cytokine fusion proteins containing IL-2, IL-12, IL-21, TNF $\alpha$, and IFN $\alpha$, IFN $\beta$, and IFN $\gamma$ to guide cytokines specifically to tumor sites where they stimulated an antitumor response.

\section{Cytokines in vaccine therapy}

Cancer treatment vaccines have only shown modest activity. However, cytokines may function as adjuvants to augment the immune response elicited by an oncolytic virus vaccine (Senzer and others 2009). The Cytokine Working Group utilized high-dose IL-2 plus HLA-A2 restricted gp100 peptide in HLAA2 patients with MM. Molecular vaccinia vaccines containing IL-15 have shown efficacy in a number of preclinical situations superior to IL-2. A multivalent HIV vaccine candidate was generated, which co-expresses Env, Gag, Pol, Nef, and Tat. In studies to address the threat of bioterrorism agents, a smallpox vaccine candidate that integrated IL-15 demonstrated superior immunogenicity, efficacy, and safety in mice (Merkel and others 2010). Furthermore, a highly efficacious vaccinia-based dual vaccine against smallpox and anthrax, 2 important bioterrorism agents, was developed. A vaccinia-based, multivalent H5 N1 avian influenza vaccine, adjuvanted with IL-15 that conferred a sterile cross-clade protection in mice, was generated (Valkenburg and others 2014). A pentavalent HPV vaccine was also developed, which expresses E1/E2, NS3, NS4, and NS5b antigens in tandem, as well as a multivalent malarial vaccine (CSP, AMA-1, MSP-1, and SSP-2).

\section{Cytokines in adoptive cell therapy}

Cytokines, predominantly IL-2, have been used to enhance the in vivo survival of adoptively transferred antitumor TIL and CAR (Kochenderfer and others 2015; Jiang and others 2015). There is evidence, however, that IL-7 and IL-15 may be superior to IL-2 due to a more favorable profile in maintaining memory $\mathrm{CD}^{+}$and $\mathrm{CD}^{+} \mathrm{T}$ cells over $\mathrm{CD} 4^{+} \mathrm{CD} 25^{+}$Foxp3 regulatory $\mathrm{T}$ antigen-specific $\mathrm{T}$ cells used in adoptive cell therapy (Yee and others 2002; Berger and others 2009). Ongoing phase II trials of cytokineinduced memory-like NK cell adoptive therapy for AML/ MDS in preallogeneic and postallogeneic hematopoietic transplant settings (NCT01898793 and NCT03068819, respectively) use IL-2, IL-9, and IL-15 for ex vivo induction, and ALT-803 (IL-15 "super-agonist") for in vivo support. Compared to IL-2, IL-2 superkine induced superior expansion of cytotoxic $\mathrm{T}$ cells, leading to improved antitumor responses in vivo and eliciting proportionally less expansion of Tregs and reduced pulmonary edema in mice.

\section{Conclusions}

Antitumor-specific immunity involves a variety of cytokines that control the balance between tumor rejection by antigenspecific effector cells and suppressor mechanisms that allow tumors to escape the immune system. Cytokines have demonstrated therapeutic antitumor activity in murine models and in clinical treatment of select human cancers. Furthermore, IFN $\alpha$ and IL-2 have been approved for the treatment of select malignancies.

Nevertheless, cytokines have not fulfilled their initial promise to become dominant factors in cancer immunotherapy. However, many novel strategies are being developed to enhance the activity of cytokines, taking into account our understanding of the regulatory mechanisms that control the immune response and that have been validated in animal models. Recently, the structure of IL-2 has been modified by genetic engineering to generate IL-2-like "superkines" that have altered the IL- $2 \mathrm{R} \alpha$ binding domains that greatly decrease the binding affinity to IL$2 \mathrm{R} \alpha$, while increasing the affinity to the IL- $2 \mathrm{R} \beta$ gamma complex, thereby increasing the action on effector $\mathrm{T}$ cells and decreasing the interaction with Tregs. Furthermore, the lack of interaction with $\mathrm{IL}-2 \mathrm{R} \alpha$ has reduced pulmonary edema in preclinical studies. The use of select anticytokine antibodies in association with the cytokine and PEGylation of the cytokine has improved the pharmacokinetics and efficacy of cytokines such as IL-2. Yet another approach to augment the action and increase the specificity of activity involved antibody-cytokine fusion proteins. Antibody-IL-2 fusion proteins containing IL-2, IL-12, IL-21, tumor necrosis factor, and IFN- $\alpha \beta \gamma$ to guide cytokines specifically to tumor sites, where they stimulate an antitumor response, while avoiding the systemic toxicity of free cytokine therapy, are being evaluated in clinical trials. These conjugates include anti-DNA and anti-phosphatidylserine to enhance tumor targeting. In yet other efforts, the addition of agents to relieve checkpoints of the immune system has been used in conjunction with cytokines. For example, studies are being initiated with the simultaneous addition of anti-CTLA-4 and anti-PD-L1 with IL-15 to yield a combination that manifested prolonged animal survival in murine models. Cytokines such as IL-2 and especially IL-15 dramatically augment the number and state of activation of NK cells. However, the action of these cells is aborted by the interaction of an inhibitory KIR or NKG2A receptor with self-class MAC A or B and E, respectively, which are expressed on the tumor cells. To address this impediment, IL-15 is being co-administered with tumordirected monoclonal antibodies to augment the NK-mediated ADCC of these anticancer monoclonal antibodies. An additional impediment to the use of gamma cytokines is that they induce the expression of CIS and SOCS3, which in turn leads to an inadequate CD4 help and induction of "helpless" CD8 T cells. Agonistic anti-CD40 monoclonal antibodies or CD40 ligand can substitute for inadequate CD4 cells, thereby leading to the generation of antigen-specific CD8 cytotoxic T cells. In murine models, the combination of an agonistic anti-CD40 monoclonal antibody and IL-15 augmented tumor-specific CD8 $\mathrm{T}$ cells and antitumor efficacy_an approach that is being translated into clinical trials. It is hoped that with these novel combination approaches, cytokines will ultimately play a major role in cancer immunotherapy.

\section{Author Disclosure Statement}

M.D.M received research funding from Pfizer Oncology. K.C.C. and T.A.W. have no potential competing financial interests to report.

\section{References}

Abrams DI, Volberding PA. 1986. Alpha interferon therapy of AIDS-associated Kaposi's sarcoma. Semin Oncol 13(3 Suppl 2): 43-47. 
Amato R. 1999. Modest effect of interferon alfa on metastatic renal-cell carcinoma. Lancet 353(9146):6-7.

Andersen R, Donia M, Westergaard MC, Pedersen M, Hansen M, Svane IM. 2015. Tumor infiltrating lymphocyte therapy for ovarian cancer and renal cell carcinoma. Hum Vaccin Immunother 11:2790-2795.

Ardolino M, Hsu J, Raulet DH. 2015. Cytokine treatment in cancer immunotherapy. Oncotarget 6(23):19346-19347.

Atkins MB, Lotze MT, Dutcher JP, Fisher RI, Weiss G, Margolin K, Abrams J, Sznol M, Parkinson D, Hawkins M, Paradise C, Kunkel L, Rosenberg SA. 1999. High-dose recombinant interleukin-2 therapy for patients with metastatic melanoma: analysis of 270 patients treated between 1985 and 1993. J Clin Oncol 17(7):2105-2116.

Bamford RN, DeFilippis AP, Azimi N, Kurys G, Waldmann TA. 1998. The 5' untranslated region, signal peptide and the coding sequence of the carboxyl terminus of IL-15 participate in its multifaceted translation control. J Immunol 160(9): 4418-4426.

Bazarbachi A, Plumelle Y, Ramos JC, Tortevoye P, Otrock Z, Taylor G, Gessain A, Harrington W, Panelatti G, Hermine O. 2010. Meta-analysis on the use of zidovudine and interferon-alfa in adult T-cell leukemia/lymphoma showing improved survival in the leukemic subtypes. J Clin Oncol 28(27):4177-4183.

Becker JC, Varki N, Gillies SD, Furukawa K, Reisfeld RA. 1996. An antibody-interleukin 2 fusion protein overcomes tumor heterogeneity by induction of a cellular immune response. Proc Natl Acad Sci U S A 93(15):7826-7831.

Bennett SRM, Carbone FR, Karamalis F, Flavell RA, Miller JF, Heath WR. 1998. Help for cytotoxic-T-cell responses is mediated by CD40 signalling. Nature 393(6684):478-480.

Berger C, Berger M, Hackman RC, Gough M, Elliott C, Jensen MC, Riddell SR. 2009. Safety and immunologic effects of IL15 administration in nonhuman primates. Blood 114(12): 2417-2426.

Boyman O, Kovar M, Rubinstein MP, Surh CD, Sprent J. 2006. Selective stimulation of T cell subsets with antibody-cytokine immune complexes. Science 311(5769):924-1927.

Boyman O, Sprent J. 2012. The role of interleukin-2 during homeostasis and activation of the immune system. Nat Rev Immunol 12(3):180-190.

Brideau-Andersen AD, Huang XJ, Sun SCC, Chen TT, Stark D, Sas IJ, Zadik L, Dawes GN, Guptill DR, McCord R, Govindarajan S, Roy A, Yang SM, Gao J, Chen YH, Skartved NJO, Pedersen AK, Lin D, Locher CP, Rebbapragada I, Jensen AD, Bass SH, Nissen TLS, Viswanathan S, Foster GR, Smons JA, Patten PA. 2007. Directed evolution of geneshuffled IFN-alpha molecules with activity profiles tailored for treatment of chronic viral diseases. Proc Natl Acad Sci U S A 104(20):8269-8274.

Caligiuri MA, Murray C, Robertson MJ, Wang E, Cochran K, Cameron C, Schow P, Ross ME, Klumpp TR, Soiffer RJ, Smith KA, Ritz J. 1993. Selective modulation of human natural-killer- cells in vivo after prolonged infusion of low dose recombinant interleukin 2. J Clin Invest 91(1):123-132.

Capitini CM, Chisti AA, Mackall CL. 2009. Modulating T-cell homeostasis with IL-7: preclinical and clinical studies. J Intern Med 266:141-153.

Carnemolla B, Borsi L, Balza E, Castellani P, Meazza R, Berndt A, Ferrini S, Kosmehl H, Neri D, Zardi L. 2002. Enhancement of the antitumor properties of interleukin-2 by its targeted delivery to the tumor blood vessel extracellular matrix. Blood 99(5):1659-1665.

Carter P. 2001. Improving the efficacy of antibody-based cancer therapies. Nat Rev Cancer 1(2):118-129.
Chen J, Petrus M, Bamford R, Shih JH, Morris JC, Janik JE, Waldmann TA. 2012. Increased serum soluble IL-15R alpha levels in T-cell large granular lymphocyte leukemia. Blood 119(1):137-143.

Chertova E, Bergamaschi C, Chertov O, Sowder R, Bear J, Roser JD, Beach RK, Lifson JD, Felber BK, Pavlakis GN. 2013. Characterization and favorable in vivo properties of heterodimeric soluble IL-15 center dot IL-15R alpha cytokine compared to IL-15 monomer. J Biol Chem 288(25):1809318103.

Conlon KC, Lugli E, Welles HC, Rosenberg SA, Fojo AT, Morris JC, Fleisher TA, Dubois SP, Perera LP, Stewart DM, Goldman CK, Bryant BR, Decker JM, Chen J, Worthy TA, Figg WD, Sr, Peer CJ, Sneller MC, Lane HC, Yovandich JL, Creekmore SP, Roederer M, Waldmann TA. 2015. Redistribution, hyperproliferation, activation of natural killer cells and CD8 T cells, and cytokine production during first-inhuman clinical trial of recombinant human interleukin-15 in patients with cancer. J Clin Oncol 33(1):74-82.

Constantinescu SN, Croze E, Wang C, Murti A, Basu L, Mullersman JE, Pfeffer LM. 1994. Role of interferon alpha/beta receptor chain-1 in the structure and transmembrane signaling of the interferon-alpha/beta receptor complex. Proc Natl Acad Sci U S A 91(20):9602-9606.

Coughlin CM, Salhany KE, Wysocka M, Aruga E, Kurzawa H, Chang AE, Hunter CA, Fox JC, Trinchieri G, Lee WM. 1998. Interleukin-12 and interleukin-18 synergistically induce murine tumor regression which involves inhibition of angiogenesis. J Clin Invest 101(6):1441-1452.

Curti BD. 2006. Immunomodulatory and antitumor effects of interleukin-21 in patients with renal cell carcinoma. Expert Rev Anticancer Ther 6(6):905-909.

Darnell JE, Jr, Kerr IM, Stark GR. 1994. Jak-STAT pathways and transcriptional activation in response to IFNs and other extracellular signaling proteins. Science 264(5164):1415-1421.

Dranoff G. 2004. Cytokines in cancer pathogenesis and cancer therapy. Nat Rev Cancer 4(1):11-22.

Dranoff G, Jaffee E, Lazenby A, Golumbek P, Levitsky H, Brose K, Jackson V, Hamada H, Pardoll D, Mulligan RC. 1993. Vaccination with irradiated tumor-cells engineered to secrete murine granulocyte-macrophage colony-stimulating factor stimulates potent, specific, and long-lasting antitumor immunity. Proc Natl Acad Sci U S A 90(8):3539-3543.

Dubois S, Mariner J, Waldmann TA, Tagaya Y. 2002. IL-15R alpha recycles and presents IL-15 in trans to neighboring cells. Immunity 17(5):537-547.

Dubois S, Patel HJ, Zhang M, Waldmann TA, Muller JR. 2008. Preassociation of IL-15 with IL-15R alpha-IgG1-Fc enhances its activity on proliferation of NK and CD8(+)/ CD44 (high) $\mathrm{T}$ cells and its antitumor action. J Immunol 180(4):2099-2106.

Evans R, Fuller JA, Christianson G, Krupke DM, Trout AB. 1997. IL-15 mediates anti-tumor effects after cyclophosphamide injection of tumor-bearing mice and enhances adoptive immunotherapy: the potential role of NK cell subpopulations. Cell Immunol 179(1):66-73.

Fallon J, Tighe R, Kradjian G, Guzman W, Bernhardt A, Neuteboom B, Lan Y, Sabzevari H, Schlom J, Greiner JW. 2014. The immunocytokine NHS-IL12 as a potential cancer therapeutic. Oncotarget 5(7):1869-1884.

Fehniger TA, Bluman EM, Porter MM, Mrózek E, Cooper MA, VanDeusen JB, Frankel SR, Stock W, Caligiuri MA. 2000. Potential mechanisms of human natural killer cell expansion in vivo during low-dose IL-2 therapy. J Clin Invest 106(1): $117-124$. 
Fehniger TA, Cooper MA, Caligiuri MA. 2002. Interleukin-2 and interleukin-15: immunotherapy for cancer. Cytokine Growth Factor Rev 13(2):169-183.

Floros T, Tarhini AA. 2015. Anticancer cytokines: biology and clinical effects of interferon- $\alpha 2$, interleukin (IL)-2, IL-15, IL21 and IL-12. Semin Oncol 42(4):539-548.

Frucht DM, Fukao T, Bogdan C, Schindler H, O’Shea JJ, Koyasu S. 2001. IFN-gamma- production by antigen-presenting cells: mechanisms emerge. Trends Immunol 22(10):556-560.

Fyfe G, Fisher RI, Rosenberg SA, Sznol M, Parkinson DR, Louie AC. 1995 . Results of treatment of 255 patients with metastatic renal-cell carcinoma who received high-dose recombinant interleukin-2 therapy. J Clin Oncol 13(3):688-696.

Gill D, Hahn AW, Sonpavde G, Agarwal N. 2016. Immunotherapy of advanced renal cell carcinoma: current and future therapies. Hum Vaccin Immunother 12(12):2997-3004.

Goldstein D, Laszlo J. 1988. The role of interferon in cancertherapy - a current perspective. CA Cancer J Clin 38(5):258275.

Gollob JA, Mier JW, Veenstra K, McDermott DF, Clancy D, Clancy M, Atkins MB. 2000. Phase I trial of twice-weekly intravenous interleukin 12 in patients with metastatic renal cell cancer or malignant melanoma: ability to maintain IFNgamma induction is associated with clinical response. Clin Cancer Res 6(5):1678-1692.

Gratama JW, Bruin RJ, Lamers CH, Oosterom R, Braakman E, Stoter G, Bolhuis RL. 1993. Activation of the immune system of cancer patients by continuous IV. recombinant IL-2 (rIL-2) therapy is dependent on dose and schedule of rIL-2. Clin Exp Immunol 92(2):185-193.

Gutterman JU, Blumenschein GR, Alexanian R, Yap HY, Buzdar AU, Cabanillas F, Hortobagyi GN, Hersh EM, Rasmussen SL, Harmon M, Kramer M, Pestka S. 1980. Leukocyte interferon-induced tumor regression in human metastatic breast cancer, multiple myeloma and malignant lymphoma. Ann Intern Med 93(3):399-406.

Heaton KM, Ju G, Grimm EA. 1993. Human interleukin-2 analogs that preferentially bind the intermediate-affinity interleukin-2 receptor lead to reduced secondary cytokine secretion - implications for the use of these interleukin 2 analogs in cancer-immunotherapy. Cancer Res 53(11):25972602.

Hu PS, Mizokami M, Ruoff G, Khawli LA, Epstein AL. 2003. Generation of low-toxicity interleukin-2 fusion proteins devoid of vasopermeability activity. Blood 101(12):4853-4861.

Isaacs A, Lindenmann J. 1957. Virus interference .1. the interferon. Proc Natl Acad Sci U S A 147(927):258-267.

Jiang SS, Tang Y, Zhang YJ, Weng DS, Zhou ZG, Pan K, Pan QZ, Wang QJ, Liu Q, He J, Zhao JJ, Li J, Chen MS, Chang AE, Li Q, Xia JC. 2015. A phase I clinical trial utilizing autologous tumor-infiltrating lymphocytes in patients with primary hepatocellular carcinoma. Oncotarget 6(38):41339-41349.

Jinushi M, Hodi FS, Dranoff G. 2008. Enhancing the clinical activity of granulocyte-macrophage colony-stimulating factor-secreting tumor cell vaccines. Immunol Rev 222:287298.

Jonasch E, Haluska FG. 2001. Interferon in oncological practice: review of interferon biology, clinical applications, and toxicities. Oncologist 6(1):34-55.

Junghans RP, Ma Q, Rathore R, Gomes EM, Bais AJ, Lo AS, Abedi M, Davies RA, Cabral HJ, Al-Homsi AS, Cohen SI. 2016. Phase I trial of anti-PSMA designer CAR-T cells in prostate cancer: possible role for interacting interleukin 2-T cell pharmacodynamics as a determinant of clinical response. Prostate 76(14):1257-1270.
Kaufman HL, Ruby CE, Hughes T, Slingluff CL, Jr. 2014. Current status of ganulocyte-macrophage colony-stimulating factor in the immunotherapy of melanoma. J Immunother Cancer 2:11.

Kennedy MK, Glaccum M, Brown SN, Butz EA, Viney JL, Embers M, Matsuki N, Charrier K, Sedger L, Willis CR, Brasel K, Morrissey PJ, Stocking K, Schuh JCL, Joyce S, Peschon JJ. 2000. Reversible defects in natural killer and memory CD8 T cell lineages in interleukin 15-deficient mice. J Exp Med 191(5):771-780.

Kirkwood JM, Ernstoff MS. 1984. Interferons in the treatment of human cancer. J Clin Oncol 2(4):336-352.

Klebanoff CA, Finkelstein SE, Surman DR, Lichtman MK, Gattinoni L, Theoret MR, Grewal N, Spiess PJ, Antony PA, Palmer DC, Tagaya Y, Rosenberg SA, Waldmann TA, Restifo NP. 2004. Il-15 enhances the in vivo antitumor activity of tumor-reactive CD8(+) T cells. Proc Natl Acad Sci U S A 101(7):1969-1974.

Kochenderfer JN, Dudley ME, Kassim SH, Somerville RP, Carpenter RO, Stetler-Stevenson M, Yang JC, Phan GQ, Hughes MS, Sherry RM, Raffeld M, Feldman S, Lu L, Li YF, Ngo LT, Goy A, Feldman T, Spaner DE, Wang ML, Chen CC, Kranick SM, Nath A, Nathan DA, Morton KE, Toomey MA, Rosenberg SA. 2015. Chemotherapy-refractory diffuse large B-cell lymphoma and indolent B-cell malignancies can be effectively treated with autologous $\mathrm{T}$ cells expressing an anti-CD19 chimeric antigen receptor. J Clin Oncol 33(6): $540-549$

Kurzrock R. 2000. Cancer medicine 5th ed. Hamilton, Canada: BC Decker.

Lasek W, Zagozdzon R, Jakobisiak M. 2014. Interleukin 12: still a promising candidate for tumor immunotherapy? Cancer Immunol Immunother 63(5):419-435.

Lee S, Margolin K. 2011. Cytokines in cancer immunotherapy. Cancers 3(4):3856-3893.

Lenardo MJ. 1996. Fas and the art of lymphocyte maintenance. J Exp Med 183(3):721-724.

Leonard JP, Sherman ML, Fisher GL, Buchanan LJ, Larsen G, Atkins MB, Sosman JA, Dutcher JP, Vogelzang NJ, Ryan JL. 1997. Effects of single-dose interleukin-12 exposure on interleukin-12-associated toxicity and interferon-gamma production. Blood 90(7):2541-2548.

Levin AM, Bates DL, Ring AM, Krieg C, Lin JT, Su L, Moraga I, Raeber ME, Bowman GR, Novick P, Pande VS, Fathman CG, Boyman O, Garcia KC. 2012. Exploiting a natural conformational switch to engineer an interleukin-2 'superkine'. Nature 484(7395):529-533.

Liao W, Lin JX, Leonard WJ. 2011. IL-2 family cytokines: new insights into the complex roles of IL-2 as a broad regulator of T helper cell differentiation. Curr Opin Immunol 23(5):598604.

Lighvani AA, Frucht DM, Jankovic D, Yamane H, Aliberti J, Hissong BD, Nguyen BV, Gadina M, Sher A, Paul WE, O'Shea JJ. 2001. T-bet is rapidly induced by interferongamma in lymphoid and myeloid cells. Proc Natl Acad Sci U S A 98(26):15137-15142.

Lu YC, Parker LL, Lu T, Zheng Z, Toomey MA, White DE, Yao X, Li YF, Robbins PF, Feldman SA, van der Bruggen P, Klebanoff CA, Goff SL, Sherry RM, Kammula US, Yang JC, Rosenberg SA. 2017. Treatment of patients with metastatic cancer using a major histocompatibility complex class IIrestricted T-cell receptor targeting the cancer germline antigen MAGE-A3. J Clin Oncol 35(29):3322-3329.

Lugli E, Goldman CK, Perera LP, Smedley J, Pung R, Yovandich JL, Jason L, Creekmore SP, Waldmann TA, Roe- 
derer M. 2010. Transient and persistent effects of IL-15 on lymphocyte homeostasis in nonhuman primates. Blood 116(17): 3238-3248.

Ma HL, Whitters MJ, Konz RF, Senices M, Young DA, Grusby MJ, Collins M, Dunussi-Joannopoulos K. 2003. IL-21 activates both innate and adaptive immunity to generate potent antitumor responses that require perforin but are independent of IFN-gamma. J Immunol 171(2):608-615.

Mach N, Dranoff G. 2000. Cytokine-secreting tumor cell vaccines. Curr Opin Immunol 12(5):571-575.

Merkel TJ, Perera PY, Kelly VK, Verma A, Llewellyn ZN, Waldmann TA, Mosca JD, Perera LP. 2010. Development of a highly efficacious vaccinia-based dual vaccine against smallpox and anthrax, two important bioterror entities. Proc Natl Acad Sci U S A 107(42):18091-18096.

Mitra S, Ring AM, Amarnath S, Spangler JB, Li P, Ju W, Fischer S, Oh J, Spolski R, Weiskopf K, Kohrt H, Foley JE, Rajagopalan S, Long EO, Fowler DH, Waldmann TA, Garcia $\mathrm{KC}$, Leonard WJ. 2015. Interleukin-2 activity can be finetuned with engineered receptor signaling clamps. Immunity 42(5):826-838.

Moga E, Alvareza E, Canto E, Vidal S, Rodriguez-Sanchez JL, Sierra J, Briones J. 2008. NK cells stimulated with IL-15 or CpG ODN enhance rituximab-dependent cellular cytotoxicity against B-cell lymphoma. Exp Hematol 36(1):69-77.

Mortier E, Quemener A, Vusio P, Lorenzen I, Boublik Y, Grotzinger J, Plet A, Jacques Y. 2006. Soluble interleukin-15 receptor alpha (IL-15R alpha)-sushi as a selective and potent agonist of IL-15 action through IL-15R beta/gammaHyperagonist IL-15 center dot IL-15R alpha fusion proteins. J Biol Chem 281(3):1612-1619.

Mueller YM, Petrovas C, Bojczuk PM, Dimitriou LD, Beer B, Silvera P, Villinger F, Cairns JS, Gracely EJ, Lewis MG, Katsikis PD. 2005. Interleukin-15 increases effector memory CD8(+) T cells and NK cells in simian immunodeficiency virus-infected macaques. J Virol 79(8):4877-4885.

Muller U, Steinhoff U, Reis LFL, Hemmi S, Pavlovic J, Zinkernagel RM, Aguet M. 1994. Functional-role of type-I and type-II interferons in antiviral defense. Science 264(5167):1918-1921.

Nicholas C, Lesinski GB. 2011. Immunomodulatory cytokines as therapeutic agents for melanoma. Immunotherapy 3(5): 673-690.

Penichet ML, Morrison SL 2001. Antibody-cytokine fusion proteins for the therapy of cancer. J Immunol Methods 248(1-2):91-101.

Pettit DK, Bonnert TP, Eisenman J, Srinivasan S, Paxton R, Beers C, Lynch D, Miller B, Yost J, Grabstein KH, Gombotz WR. 1997. Structure-function studies of interleukin 15 using sitespecific mutagenesis, polyethylene glycol conjugation, and homology modeling. J Biol Chem 272(4):2312-2318.

Quesada JR, Hersh EM, Manning J, Reuben J, Keating M, Schnipper E, Itri L, Gutterman JU. 1986. Treatment of hairycell leukemia with recombinant alpha-interferon. Blood 68(2):493-497.

Ratain MJ, Golomb HM, Vardiman JW, Vokes EE, Jacobs RH, Daly K. 1985. Treatment of hairy-cell leukemia with recombinant alpha-2 interferon. Blood 65(3):644-648.

Reisfeld RA, Gillies SD. 1996. Antibody-interleukin 2 fusion proteins: a new approach to cancer therapy. J Clin Lab Anal 10(3):160-166.

Ridge JP, Di Rosa F, Matzinger P. 1998. A conditioned dendritic cell can be a temporal bridge between a CD4(+) Thelper and a T-killer cell. Nature 393(6684):474-478.

Roberti MP, Barrio MM, Bravo Al, Rocca YS, Arriaga JM, Bianchini M, Mordoh J, Levy EM. 2011. IL-15 and IL-2 increase Cetuximab-mediated cellular cytotoxicity against triple negative breast cancer cell lines expressing EGFR. Breast Cancer Res Treat 130(2):465-575.

Rochman Y, Spolski R, Leonard WJ. 2009. New insights into the regulation of $\mathrm{T}$ cells by gamma(c) family cytokines. Nat Rev Immunol 9(7):480-490.

Romee R, Rosario M, Berrien-Elliott MM, Wagner JA, Jewell BA, Schappe T, Leong JW, Abdel-Latif S, Schneider SE, Willey S, Neal CC, Yu LY, Oh ST, Lee YS, Mulder A, Claas F, Cooper MA, Fehniger TA. 2016. Cytokine-induced memory-like natural killer cells exhibit enhanced responses against myeloid leukemia. Sci Transl Med 8(357):357ra123.

Rosenberg SA, Lotze MT, Yang JC, Aebersold PM, Linehan WM, Seipp CA, White DE. 1989. Experience with the use of high-dose interleukin-2 in the treatment of 652 cancerpatients. Ann Surg 210(4):474-485.

Rosenberg SA, Sportes C, Ahmadzadeh M, Fry TJ, Ngo LT, Schwarz SL, Stetler-Stevenson M, Morton KE, Mavroukakis SA, Morre M, Buffet R, Mackall CL, Gress RE. 2006. IL-17 administration to humans leads to expansion of CD8 $(+)$ and CD4(+) cells but a relative decrease of CD4(+) T-regulatory cells. J Immunother 29(3):313-319.

Rotte A, Bhandaru M, Zhou Y, McElwee KJ. 2015. Immunotherapy of melanoma: present options and future promises. Cancer Metastasis Rev 34(1):115-128.

Sadlack B, Kuhn R, Schorle H, Rajewsky K, Muller W, Horak I. 1994. Development and proliferation of lymphocytes in mice deficient for both interleukin-2 and interleukin-4. Eur J Immunol 24(1):281-284.

Sakaguchi S, Sakaguchi N, Asano M, Itoh M, Toda M. 1995. Immunological self-tolerance maintained by activated T-cells expressing Il-2 receptor alpha-chains (CD25)-breakdown of a single mechanism of self-tolerance causes various autoimmune-diseases. J Immunol 155(3):1151-1164.

Sandau MM, Schluns KS, Lefrancois H, Jameson SC. 2004. Cutting edge: transpresentation of IL-15 by bone marrowderived cells necessitates expression of IL-15 and IL-15R alpha by the same cells. J Immunol 173(11):6537-6541.

Schoenberger SP, Toes REM, van der Voort EIH, Offringa R, Melief CJM. 1998. T-cell help for cytotoxic T lymphocytes is mediated by CD40-CD40 L interactions. Nature 393(6684): 480-483.

Schrama D, Reisfeld RA, Becker JC. 2006. Antibody targeted drugs as cancer therapeutics. Nat Rev Drug Discov 5(2):147159.

Sckisel GD, Bouchlaka MN, Monjazeb AM, Crittenden M, Curti BD, Wilkins DEC, Alderson KA, Sungur CM, Ames E, Mirsoian A, Reddy A, Alexander W, Soulika A, Blazar BR, Longo DL, Wiltrout RH, Murphy WJ. 2015. Out-of-sequence Signal 3 paralyzes primary CD4(+) T-cell-dependent immunity. Immunity 43(2):240-250.

Senzer NN, Kaufman HL, Amatruda T, Nemunaitis M, Reid T, Daniels G, Gonzalez R, Glaspy J, Whitman E, Harrington K, Goldsweig H, Marshall T, Love C, Coffin R, Nemunaitis JJ. 2009. Phase II clinical trial of a granulocyte-macrophage colony-stimulating factor-encoding, second-generation oncolytic herpesvirus in patients with unresectable metastatic melanoma. J Clin Oncol 27(34):5763-5771.

Sim GC, Radvanyi L. 2014. The IL-2 cytokine family in cancer immunotherapy. Cytokine Growth Factor Rev 25(4):377-390.

Skak K, Kragh M, Hausman D, Smyth MJ, Sivakumar PV. 2008. Interleukin 21: combination strategies for cancer therapy. Nat Rev Drug Discov 7(3):231-240.

Sneller MC, Kopp WC, Engelke KJ, Yovandich JL, Creekmore SP, Waldmann TA, Lane HC. 2011. IL-15 administered by 
continuous infusion to rhesus macaques induces massive expansion of CD8(+) $\mathrm{T}$ effector memory population in peripheral blood. Blood 118(26):6845-6848.

Soiffer RJ, Murray C, Shapiro C, Collins H, Chartier S, Lazo S, Ritz J. 1996. Expansion and manipulation of natural killer cells in patients with metastatic cancer by low-dose continuous infusion and intermittent bolus administration of interleukin 2. Clin Cancer Res 2(3):493-499.

Sondel PM, Hank JA. 1997. Combination therapy with interleukin-2 and antitumor monoclonal antibodies. Cancer J Sci Am 3 Suppl 1:S121-S127.

Spangler JB, Moraga I, Mendoza JL, Garcia KC. 2015. Insights into cytokine-receptor interactions from cytokine engineering. Annu Rev Immunol 33:139-167.

Spitler LE, Weber RW, Allen RE, Meyer J, Cruickshank S, Garbe E, Lin HY, Soong SJ. 2009. Recombinant human granulocyte-macrophage colony-stimulating factor (GM-CSF, sargramostim) administered for 3 years as adjuvant therapy of stages II(T4), III, and IV melanoma. J Immunother 32(6): 632-637.

Spolski R, Leonard WJ. 2008. Interleukin-21: Basic biology and implications for cancer and autoimmunity. Annu Rev Immunol 26:57-79.

Spolski R, Leonard WJ. 2014. Interleukin-21: a double-edged sword with therapeutic potential. Nat Rev Drug Discov 13(5): 381-393.

Sportès C, Babb RR, Krumlauf MC, Hakim FT, Steinberg SM, Chow CK, Brown MR, Fleisher TA, Noel P, Maric I, StetlerStevenson M, Engel J, Buffet R, Morre M, Amato RJ, Pecora A, Mackall CL, Gress RE. 2010. Phase I study of recombinant interleukin-7 administration in subjects with refractory malignancy. Clin Cancer Res 16(2):727-735.

Steel JC, Waldmann TA, Morris JC. 2012. Interleukin-15 biology and its therapeutic implications in cancer. Trends Pharmacol Sci 33(1):35-41.

Steele N, Anthony A, Saunders M, Esmarck B, Ehmrooth E, Kristjansen PEG, Nihlen A, Hansen LT, Cassidy J. 2012. A phase 1 trial of recombinant human IL-21 in combination with cetuximab in patients with metastatic colorectal cancer. Br J Cancer 106(5):793-798.

Stemmer WPC. 1994. Rapid evolution of a protein in-vitro by DNA shuffling. Nature 370(6488):389-391.

Street SEA, Trapani JA, MacGregor D, Smyth MJ. 2002. Suppression of lymphoma and epithelial malignancies effected by interferon gamma. J Exp Med 196(1):129-134.

Sugaya M, Tokura Y, Hamada T, Tsuboi R, Moroi Y, Nakahara T, Amano M, Ishida S, Watanabe D, Tani M, Ihn H, Aoi J, Iwatsuki K. 2014. Phase II study of i.v. interferon-gamma in Japanese patients with mycosis fungoides. J Dermatol 41(1):50-56.

Taniguchi T, Minami Y. 1993. The IL-2/IL-2 receptor system-a current overview. Cell 73(1):5-8.

Tarhini AA, Cherian J, Moschos SJ, Tawbi HA, Shuai Y, Gooding WE, Sander C, Kirkwood JM. 2012. Safety and efficacy of combination immunotherapy with interferon alfa$2 \mathrm{~b}$ and tremelimumab in patients with stage IV melanoma. J Clin Oncol 30(3):322-328.

Tinhofer I, Marschitz I, Henn T, Egle A, Greil R. 2000. Expression of functional interleukin-15 receptor and autocrine production of interleukin-15 as mechanisms of tumor propagation in multiple myeloma. Blood 95(2):610-618.

Trinchieri G. 2003. Interleukin-12 and the regulation of innate resistance and adaptive immunity. Nat Rev Immunol 3(2): 133-146.

Valkenburg SA, Li OTW, Mak PWY, Mok CKP, Nicholls JM, Guan Y, Waldmann TA, Peiris JSM, Perera LP, Poon LLM.
2014. IL-15 adjuvanted multivalent vaccinia-based universal influenza vaccine requires CD4(+) T cells for heterosubtypic protection. Proc Natl Acad Sci U S A 111(15): 5676-5681.

Vincent M, Teppaz G, Lajoie L, Sole V, Bessard A, Maillasson M, Loisel S, Bechard D, Clemenceau B, Thibault G, GarrigueAntar L, Jacques Y, Quemener A. 2014. Highly potent antiCD20-RLI immunocytokine targeting established human B lymphoma in SCID mouse. MABS 6(4):1026-1037.

Waldmann TA. 1986. The structure, function, and expression of interleukin-2 receptors on normal and malignant lymphocytes. Science 232(4751):727-732.

Waldmann TA. 2006. The biology of interleukin-2 and interleukin-15: implications for cancer therapy and vaccine design. Nat Rev Immunol 6(8):595-601.

Waldmann TA. 2015. The shared and contrasting roles of IL-2 and IL-15 in the life and death of normal and neoplastic lymphocytes: implications for cancer therapy. Cancer Immunol Res 3(3):219-227.

Waldmann TA, Chen J. 2017. Disorders of the JAK/STAT pathway in $\mathrm{T}$ cell lymphoma pathogenesis: implications for immunotherapy. Annu Rev Immunol 35:533-550.

Waldmann TA, Lugli E, Roederer M, Perera LP, Smedley JV, Macallister RP, Goldman CK, Bryant BR, Decker JM, Fleisher TA, Lane HC, Sneller MC, Kurlander RJ, Kleiner DE, Pletcher JM, Figg WD, Yovandich JL, Creekmore SP. 2011. Safety (toxicity), pharmacokinetics, 'immunogenicity, and impact on elements of the normal immune system of recombinant human IL-15 in rhesus macaques. Blood 117(18):4787-4795.

Wang G, Tschoi M, Spolski R, Lou YY, Ozaki K, Feng CG, Kim G, Leonard WJ, Hwu P. 2003. In vivo antitumor activity of interleukin 21 mediated by natural killer cells. Cancer Res 63(24):9016-9022.

Wang XQ, Rickert M, Garcia KC. 2005. Structure of the quaternary complex of interleukin-2 with its alpha, beta, and gamma(c) receptors. Science 310(5751):1159-1163.

Windbichler GH, Hausmaninger H, Stummvoll W, Graf AH, Kainz C, Lahodny J, Denison U, Müller-Holzner E, Marth C. 2000. Interferon-gamma in the first-line therapy of ovarian cancer: a randomized phase III trial. Br J Cancer 82(6):11381144.

Yee C, Thompson JA, Byrd D, Riddell SR, Roche P, Celis E, Greenberg PD. 2002. Adoptive T cell therapy using antigenspecific CD8(+) $\mathrm{T}$ cell clones for the treatment of patients with metastatic melanoma: in vivo persistence, migration, and antitumor effect of transferred T cells. Proc Natl Acad Sci U S A 99(25):16168-16173.

Young PA, Morrison SL, Timmerman JM. 2014. Antibodycytokine fusion proteins for treatment of cancer: engineering cytokines for improved efficacy and safety. Semin Oncol 41(5):623-636.

Yu P, Steel JC, Zhang ML, Morris JC, Waitz R, Fasso M, Allison JP, Waldmann TA. 2012. Simultaneous inhibition of two regulatory T-cell subsets enhanced interleukin-15 efficacy in a prostate tumor model. Proc Natl Acad Sci U S A 109(16):6187-6192.

Yu P, Steel JC, Zhang ML, Morris JC, Waldmann TA. 2010. Simultaneous blockade of multiple immune system inhibitory checkpoints enhances antitumor activity mediated by interleukin15 in a murine metastatic colon carcinoma model. Clin Cancer Res 16(24):6019-6028.

Zaidi MR, Merlino G. 2011. The two faces of interferon-gamma in cancer. Clin Cancer Res 17(19):6118-6124.

Zhang ML, Ju W, Yao ZS, Yu P, Wei BR, Simpson RM, Waitz R, Fasso M, Allison JP, Waldmann TA. 2012. Augmented IL- 
$15 \mathrm{R}$ alpha expression by CD40 activation is critical in synergistic CD8 T cell-mediated antitumor activity of anti-CD40 antibody with IL-15 in TRAMP-C2 tumors in mice. J Immunol 188(12):6156-6164.

Zhang ML, Yao ZS, Dubois S, Ju W, Muller JR, Waldmann TA. 2009. Interleukin-15 combined with an anti-CD40 antibody provides enhanced therapeutic efficacy for murine models of colon cancer. Proc Natl Acad Sci U S A 106(18): 7513-7518.

Zhu XY, Marcus WD, Xu WX, Lee HI, Han KP, Egan JO, Yovandich JL, Rhode PR, Wong HC. 2009. Novel human interleukin-15 agonists. J Immunol 183(6):3598-3607.
Address correspondence to:

Dr. Thomas A. Waldmann Lymphoid Malignancies Branch Center for Cancer Research National Cancer Institute Building 10

Room 4 N115

Bethesda, MD 20892-1374

E-mail: tawald@helix.nih.gov

Received 7 February 2018/Accepted 15 March 2018 